\title{
DEMOCRACY OR MILITARY DICTATORSHIP: A CHOICE OF GOVERNANCE FOR THE ECONOMIC GROWTH OF PAKISTAN
}

\author{
Shakeel Qadir ${ }^{1}$ \\ Institute of Business \& Technology \\ Muhammad Tariq ${ }^{2}$ \\ Institute of Business \& Technology \\ Muhammad Waqas ${ }^{3}$ \\ Institute of Business \& Technology
}

\begin{abstract}
Purpose:-This study is conducted to find out whether democratic or nondemocratic governments bring greater economic growth to Pakistan.

Methodology:-The data of economic growth from the bureau of statistics is taken for the period 1947(Pakistan's independence) to 2009 which includes four major democratic and four major autocratic era's. Findings:-With the help of independent sample t-test it is concluded that growth has been better in the periods of autocratic rule with significant difference in areas such as GDP growth rate, CPI inflation, Floating debt and insignificant difference in areas such as Exports, Health Expenditure, FDI, and Electricity generation

Practical Implications:-The study will help the related departments in forming the effective policies viable for economic growth and development of the country. This study sheds light on the performance of the major types of government systems in terms of economic and social growth
\end{abstract}

Key Words: HR Diversity Management, Trust on Leadership, Cooperative Norms, Knowledge Sharing.

\footnotetext{
* The material presented by the author does not necessarily portray the viewpoint of the editors and the management of the Institute of Business \& Technology (IBT)

1 Shakeel Qadir

2 Muhammad Tariq

3 Muhammad Waqas

:shakeel.qadir@gmail.com :m.tariq1985@gmail.com :m_waqas74@yahoo.com

C IBT-JBS is published by the Institute of Business and Technology (IBT).

Main Ibrahim Hydri Road, Korangi Creek, Karachi-75190, Pakistan.
} 


\section{INTRODUCTION}

\subsection{Overview}

Economic growth is and always has been the key to assessing a country's worth and standing in the world. The rate of increase or decrease of it reflects the quality of leadership of a country and is the basis upon which the country's performance is measured. Over the years the debate of whether democratic or non-democratic governments are better for the economic growth, have gained momentum and attracted focus of the masses.

Democracy and democratic government have gained such popularity and support from nations with popular say that it is almost considered a faith, and speaking against it or questioning it is considered synonymous to blasphemous speech. However the recent events have also showed that even strongest democracies are not immune to great economic shocks and that democratic regime alone cannot save from economic catastrophes.

For countries like Pakistan where political system changes like the musical chair, this discussion is not confined to the media and civil society, but is also the tea talk of taxi drivers and the buddy talk of school going kids.

It is for these reasons that a review of this debate is necessary to find out whether democracy does any good to the economy. Or is it the authoritarian regimes which by monitoring the growth determinants perform better, especially in the context of a country of Pakistan.

\subsubsection{Background of the Study Historical Aspect}

Pakistan's political scenario has unique history of unstable government systems and frequent dethroning of democratic governments and its replacement by military rulers imposing martial law so much as that almost half of the 68 years of Pakistan have passed under martial law and authoritarian forms of government. Since its inception in 1947 the country has undergone 3military rules between which there were controlled democracies too. The first was brought by general Iskandar Mirza which lasted from 1958 to 1971, Pakistan also remained a presidential republic in this period under the control of General Ayub Khan; the second military rule was imposed by General Ziaul-haq who removed Zulfiqarali Bhutto from his seat, it lasted from 1977 to 1988 after the General's death in a plane crash, and the third was brought by General Parvez Musharraf who toppled then Prime Minister Nawa Sharif: His rule lasted from 1999 to 2007. The economic Development conditions of the country have never been better, though economic growth figures keep fluctuating and it is yet to be decided if any form of government has special implications on it. 


\subsubsection{Significance of the Study}

In countries like Pakistan where democratic system is confined merely to the ballot box, no significance improvement is seen in such government; people long for it as it makes circumventing laws easy.

This study will bring to light the factors responsible for economic growth, to show what this country really needs rather than what it wants or demands.

\subsubsection{Objectives}

Curiosity to know about the economic growth of one's country is common to everyone. In a country such as Pakistan where political instability is a matter of routine, knowing what is better for the country and what not is even more appealing. The aim of this study is to find out if democratic governments bring better economic growth to a country or non-democratic regimes, on the basis of various growth indicators in the light of existing literature on the subject.

\subsection{Proposed Variables}

The variables that are going to be used in this study to measure Economic performance are GDP, GDP per Capita, GDP growth rate, unemployment rate, and Inflation.

\subsection{Hypotheses of the Study}

H1: There is significant difference in the GDP during the democracy and non-democracy. $\mathrm{H} 2$ : There is significant difference in the FDI during the democracy and non-democracy. H3: There is significant difference in Export during the democracy and non-democracy. $\mathrm{H} 4$ : There is significant difference in CPI Inflation during the democracy and nondemocracy.

H5: There is significant difference in Permanent debt during the democracy and nondemocracy.

H6: There is significant difference in Floating debt during the democracy and nondemocracy.

H7: There is significant difference in Foreign Aid during the democracy and nondemocracy.

H8: There is significant difference in Electricity Generation during the democracy and non-democracy.

H9: There is significant difference in Health Expenditure during the democracy and non-democracy.

H10: There is significant difference in Primary school enrollment during the democracy and non-democracy

H11: There is significant difference in Secondary school enrollment during the democracy and non-democracy

H12: There is significant difference in College school enrollment during the democracy 
and non-democracy

\subsubsection{Democracy}

Democracy per se is a system of government where the masses of a country are represented in the legislature through their elected political person elected by them in a vote. The term was defined by Abraham Lincoln as "Government of the people, for the people, and by the people." However we exclude controlled democracies from this definition and treat them as non-democracies for the sake of this study as a government democratic by its name only does not serve our purpose.

\subsubsection{Economic Growth}

time.

Economic growth is the increase in the wealth of a country over a period of

Although there are many factors used to calculate it, the most common and widely used are Gross domestic product (GDP) and gross National Product (GNP), the former includes all the wealth created by producing goods and services within the geographical boundaries of a country in a given fiscal period usually a year and the latter means all the income earned by the citizens of a country whether at home or abroad. To determine the pace of economic growth, the rate of economic growth is measured and compared to other countries. As inflation can misguide when in really appreciating the economic growth, inflation adjusted growth is often taken into account, and because values of currencies keep fluctuating, some particular year's currency rate is taken as a base year to calculate the coming years' performance. The GDP of a country is always viewed in relation to its population; the GDP when divided by the population gives GDP per capita income. Countries with large populations have smaller GDP per capita figures than those with smaller populations.

To gain further accuracy GDP per capita PPP or GDP purchasing power parity measure is used which can tell the purchasing power of say one dollar in US and in some other country for example Pakistan. A person in Pakistan may get a bigger basket of goods for the equivalent of one dollar than a person in the United States, a person in Iran may get an even bigger basket for the same amount.

\subsubsection{Economic Development}

While economic growth comprises of a country's growth of economic output in terms of GDP, GDP Per Capita, growth rate of the two, balance of trade, and inflation etc, economic development is a wider term which encompasses all the aspects social, political, and institutional changes of human development i.e Life Expectancy, mortality, literacy rate, quality of life, human rights, freedom of expression etc as well social, political, and institutional changes that accompany changes in output; we simply put aside these arguments over semantics and use growth and development interchangeably. Broadly speaking economic development consists of a broad set of changes in society and economy that increase real per capita output. That is economic development is the 
entire process that results in higher output per person.

\section{LITERATURE REVIEW}

Abrams and Lewis (1995) performed a cross-sectional analysis of cultural and institutional determinants of economic growth. They studies growth rate of economy of 90 countries over a period of 20 years and found that democracies bring more growth to a country all other things held constant.

Ahmed (2013) performed a comparative study on Pakistan's external debts under democratic and military regimes with the aim of evaluating the financial performance under both types of governments. He took official World Bank data of 42 years from 1972 to 2012 and used independent sample T-test. He found that democratic regimes have larger average increase rates of external debt as compared to nondemocratic regimes.

Alesina, Ozler, Roubini, and Swagel (1996) worked on Political instability and Economic growth. The study was aimed at finding the causal effect of the former on the latter. Cross sectional and panel data methodology was used. Growth rates of 113 countries

were observed for the period of 1950-1982. It was concluded that a significant correlation existed as growth rates showed decrease in periods of political Instability. Bardhan (1999) wrote on democracy-dictatorship relationship and concluded that democracies are better for private sector to prosper for the reason of predictability. Businesses do not succeed in the environment of uncertainty where the life of the project can be affected by political changes.

Barro (1996) performed a empirical study on "Determinants of Economic Growth". Panel data from 1960 to 1990 was taken of 100 different countries. Several determinants of Economic development and growth were taken. It was concluded that better conditions of economic development including political rights result in increased economic growth rate which remains so till a moderate level. It was also established that there is strong reverse causality among democracy and standard of living.

Bhagwatti (1995) studied democracy and development wherein she focused on many aspects of democracy and opined that authoritative regimes bottle-up problems whereas democratic ones provide a valve for these to pass through. Brunetti and Wedde (1994) studied the political sources of growth with the objective of critically reviewing the literature to find out if there is any link among political setup and economic performance. They surveyed 28 prominent studies pertinent to establishing democracy's good, bad, minimal, and zero effects on economic growth. They find evidence in existing measures in cross country growth studies, mixed, and conclude that political variable is not measured adequately by the researchers because relevant economic features of political systems are not captured in the studies. Democratic countries which provided better figures of economic and civil freedom 
Democracy or Military Dictatorship: A Choice of Governance for the Economic Growth of Pakistan

higher per capita incomes and the reverse impact of per capita incomes on governance separately. In the empirical study in which they apply governance indicators used worldwide on latin American countries, their results confirm the importance of good governance for development and reject the effect vice versa.

Kayani, Arif, and Kayani(2012) reviewed the three existing schools of thought in the existing literature on the democracy-growth relationship claiming democracy's direct, indirect and null relationship with growth. Different democracy and growth measures were taken. After analysis of research on the topic made between 1989 and 2010 it was concluded that the relationship is not concrete. However partial agreement was placed in support of the advocates of direct and positive relationship between the two.

Khan (2012)worked on "The Military and Economic Development in Pakistan" he visited the various literature on the economic development of different countries as well as that of Pakistan, He compared economic development standings of the country from the year 1990 to 2007 between military and civilian rule, and in the context of development concluded that the military's impact on economic life is not efficient and it repels the activities of private sector thereby reducing investment. Nelson and Singh (1998) worked on "Democracy, Economic freedom, Fiscal policy, and Growth in LDCs". Their objectives were threefold: evaluating growth-democracy relationship in light of conditioning factors in existing literature and finding clear evidence if democracy impacted economic growth. On the basis of data drawn from the internationally renowned publications and Gastill's work on democracy and economic freedom they built a period fixed model wherein they analyzed performance of 67 LDCs over 5-year intervals between 1979 and 1990. They conclude that: Olson, Sarna, and Swamy (2000) worked on governance and growth. They compared the World Bank provided data of 63 to 68 countries with focus on GDP, GDP growth rate, per capita income etc for the period 1960 to 1987 and concluded that quality of governance can bring exceptional economic growth even and specially to developing countries having very low income per capita.

Przeworski and Limongi (1993) studied "political regimes and economic growth" through the existing literature with the aim to find out whether correct growth determinants have been used and relevant methodology is applied. Through the application of statistical test on the result of previous research that democracy or non-democratic regimes do not exactly impact growth, instead it is something else that does and which is yet to be found is it is not clear in the contemporary work.

Serowy and Inkeles (1990) also studied on "the effects of political democracy on growth" by comparing different studies aimed at finding out different correlations. With the help of cross-national tests they analyzed their results and conclude with no significant relationship/ impact of democracy on growth.

Shen (2002)worked on democracy and growth wherein he compared 40 countries' economic performance of pre and post-democratic transition periods. Through the help of statistical tests he found that democratic transition certainly affects growth however the same is positive in case of a poor country's transition to democracy and negative 
2010 and with the help of variables such as GDP, GDP per capita, Net Exports, and taxes etc and independent T-test methodology concluded that growth of the country has been better under non democratic governments compared to the democratic ones. They further emphasize that economic prosperity of countries depends upon better governance regardless of the political system providing it.

Traves and Warcziarg(2000) empiricaly examined the effect of democracy on growth on the basis of determinants such as political instability, government expenditures and poverty etc. They found that democracy has both good and adverse impacts on economy, and conclude that in totality the impact is negative the reason being huge public sector consumption.

Kuzman, Werum, and Burkhart (2002) look for the relationship between democracy and economic growth. They use pooled time series data of 1951-1980 and conclude that no direct and significant relationship between the two exist however few indirect iompacts of democracy do. Burkhart and Lewis-Beck (1994) in support of the assumption that Economic development paves way for democracy, conduct a study in which pooled time series data of 131 countries and confirm the assumption with statistically significant results.

Polterovich, and Propov (2007) study the impact of democratization on economic growth with preconditions i.e law and order. They break up their assumption in contrast to the previous literature in this way. Their results show that where in countries the law and order is better, then democracy fosters growth, whereas in countries with poor law and order it undermines growth by making way for shadow economy. Rivera-Batiz (2002) studied the effect of democracy on good governance and on economic growth ultimately. The study first confirmed the positive causal effect of democracy on good governance, and then analyzed the effect of democracy on economic growth in democracy improving countries.

Rigobon and Rodrik (2005) study the different interrelationships i.e Income Levels, trade openness, Democracy, and Rule of Law. They distribute their sample of countries with respect of geographic locations of their continents. The study finds a strongly positive effect of rule of law on income levels and a negative impact of trade openness on income. They also conclude that democracy and rule of law crate way for each other.

\section{RESEARCH METHODS}

\subsection{Method of Data Collection}

The data for this research is secondary and has been taken from most authentic sources of the state records i.e The bureau of statistics. 


\subsection{Sampling Technique}

The data of economic growth in the first four democratic and four military governments is taken. The Mean has been taken for all the years of democratic and all the years of non-democratic governments' years separately to check the performance.

\subsection{Sample Size}

Our sample includes the economic growth data of Pakistan from independence till 2009.

\subsection{Research Model developed}

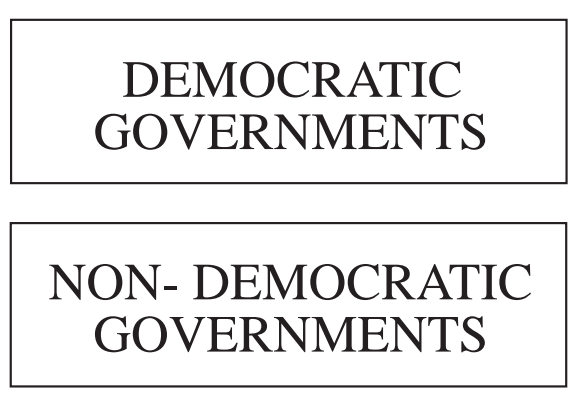

\begin{tabular}{|l|l|}
\hline$\cdot$ GDP Growth \\
$\cdot$ FDI \\
$\cdot$ Increased Exports \\
$\cdot$ Less Imports \\
$\cdot$ More Electricity \\
Power Generation and \\
Installed Capacity \\
$\cdot$ Greater Reserves \\
$\cdot$ Less Floating Debts \\
$\cdot$ Lesser foreign aid \\
$\cdot$ Less permanent Debt \\
$\cdot$ Low Inflation \\
$\cdot$ Greater Health Expenditure \\
$\cdot$ Greater primary/secondary/ \\
college/university \\
Enrollment \\
\hline
\end{tabular}

The above conceptual framework shows the various economic and social growth indicators on the right and two major types of political systems on the lift and hence portrays the lasting debate of whether democracy is better for growth or non-democratic setups. The variables shown in the figure are both economic and social. If one type of government is better, this would mean that most if not all of the performance indicators shown on the right side should show improvement. If most if not all of these indicators show negative figures, this would imply that the economic growth has been negative/poor.

\subsection{Statistical Technique (which one used and why in context with previous work)}

The statistical technique used in this study is the independent sample T-Test, which is used to compare averages taken separately. 
the average figures in both type of eras. The table shows the better of the two mean values of all the variables next to them. (See Table 4.1)

In the table 4.1, it can be seen that the mean of only 3 variables i.e imports, permanent debt, and secondary enrollment have been slightly better in the democratic governments whereas all the other 13 variables i.e GDP growth rate, Exports, FDI, CPI, Total reserves, Floating debt, Electricity Installed capacity, Electricity Generation, health Expenditure, and Primary/Secondary/college/university enrollment show better mean in the periods of non-democratic governments.

After the application of Levene's test, it is established that 4 variables out of the total of 16, show sig value to be less than 0.05. (See Table 4.2)

The table 4.2 shows the four variables having significant difference in the two eras. From table 4.0 we can see that the variables Total Reserves (Millions Rupees), Floating debt(Million Rupees) and Health Expenditure(\% of GDP) have better mean values under Non-democratic governments, and the variable Permanent Debt(Million Rupees) has better mean value under democratic Governments.

The table 4.3 shows the three variables having significant differences according to T-test. The last column shows the category of governments in which the mean performance has been better as per results shown in table 4.1 above. According to the above results only three hypothesis are accepted which means that significant difference in performance between the democratic and non democratic governments from 1947 to 2009 has been found in regard to only three output indicators that are GDP, CPI Inflation and Floating debt.

\section{DISCUSSIONS, CONCLUSION, POLICY IMPLICATIONS AND FUTURE RESEARCH}

\subsection{Discussions}

This study was aimed at finding out which of the two i.e. democratic or nondemocratic governments prove better for economic growth/development. Results indicate that non-democratic ones have proved better. Numerous studies have been conducted to find out the same from various angles; some studies have been aimed at finding out performance on specific indicators such as foreign loans taken; others have looked for institutional development in different governments; some at political rights, free press, etc.. Of all the studies, those focusing on development in third world countries have often voted for the autocratic governments. Many researchers are of the view that developing countries cannot endure democracies. Some studies have found democracy better than autocracy. However a lot of studies have failed to find out the exact effect of democracy or autocracy on economic performance as they find this line connecting democracy to economic growth very blur. The results of this study too have rejected 13 of the 16 hypotheses suggesting that no significant difference in performance was found on the basis of those factors. 


\subsection{Conclusion}

The results of this study show that non-democratic governments have been better for the economic growth of Pakistan having significantly better results in terms of indicators such as GDP growth, CPI Inflation, and Floating debts and slightly better in terms of variables such as FDI, Exports, Total reserves, Electricity generation and Installed capacity etc with insignificant differences.

\subsection{Policy Implications}

This study sheds light on the performance of the major types of government systems in terms of economic and social growth. The peak economic growth however better in the military years is still not any way near the developed countries. This study therefore provides acts as a mirror to the politicians and policy makers of the country to consider the serious 1 ssue of economic growth and development and divert their efforts to infrastructure development.

\subsection{Future Research}

The problems with developing countries such as Pakistan are not adequately caught in studies based on figures a myriad of activities run in the shadow economy. Similarly there are many problems too which are not to be found in official publications. It is therefore suggested that case study based research be carried out to find out the condition of the poorest in the country as the best picture of a country's prosperity can be judged from the condition of the poor.

Secondly research should be focused at economic development instead of Economic growth alone.

\section{REFERENCES}

Abrams, B. A., \& Lewis, K. A. (1995). Cultural and institutional determinants of economic growth: a cross-section analysis. Public Choice, 83(3-4), 273-289.

Alesina, A., Özler, S., Roubini, N., \&Swagel, P. (1996).Political instability and economic growth.Journal of Economic growth, 1(2), 189-211.

Arif, B. W., Kayani, F. N., \&Kayani, M. U. N. (2012). The Interrelationship between Democracy and Economic Growth: Theories and Empirics. Pakistan Journal of Social Sciences (PJSS), 32(1), 199-208.

Bardhan, P. (1999). Democracy and development: A complex relationship. Democracy's Value, 95-96.

Barro, R. J. (1996). Determinants of economic growth: a cross-country empirical study 
(No.w5698). National Bureau of Economic Research.

Bhagwati, J. N. (2002). Democracy and development: Cruel dilemma or symbiotic relationship?.Review of Development Economics, 6(2), 151-162.

Brunetti, Y., \&Weder, B. (1995). Political sources of growth: A critical note on measurement Public Choice, 82(1-2), 125-134.

Burkhart, R. E., \& Lewis-Beck, M. S. (1994). Comparative democracy: the economic development thesis. American Political Science Review, 88(04), 903-910.

Gerring, J., Bond, P., Barndt, W. T., \& Moreno, C. (2005). Democracy and economic growth: A historical perspective. World Politics, 57(03), 323-364.

Helliwell, J. F. (1994). Empirical linkages between democracy and economic growth.British journal of political science, 24(02), 225-248.

Iqbal, Z., \&Zahid, G. M. (1998).Macroeconomic determinants of economic growth in Pakistan.The Pakistan Development Review, 125-148.

Kaufmann, D., \&Kraay, A. (2002).Growth without governance.World Bank Policy Research Working Paper, (2928).

Khan, S. (2012). The military and economic development in Pakistan.Political Economy Research Institute, University of Massachusetts working paper series, 291.

Kurzman, C., Werum, R., \& Burkhart, R. E. (2002). Democracy's effect on economic growth: a pooled time-series analysis, 1951-1980. Studies in Comparative International Development, 37(1), 3-33.

Nawaz, A. (2013). External Debts: A Comparative Study of Pakistan in Democratic and Military Regimes. Journal of Business Strategies, 7(1).

Nelson, M. A., \& Singh, R. D. (1998). Democracy, economic freedom, fiscal policy, and growth in LDCs: a fresh look. Economic Development and Cultural Change, 46(4), 677-696.

Olson Jr, M., Sarna, N., \&Swamy, A. V. (2000). Governance and growth: A simple hypothesis explaining cross-country differences in productivity growth. Public Choice, 102(3-4), 341-364.

Polterovich, V., \& Popov, V. (2007).Democratization, quality of institutions and economic growth.Quality of Institutions and Economic Growth (July 2007).

Przeworski, A., \&Limongi, F. (1993).Political regimes and economic growth.The journal of economic perspectives, 51-69. 
Rigobon, R., \&Rodrik, D. (2005). Rule of law, democracy, openness, and income. Economics of transition, 13(3), 533-564.

Rivera-Batiz, F. L. (2002). Democracy, governance, and economic growth: theory and evidence. Review of Development Economics, 6(2), 225-247.

Shen, J. G. (2002). Democracy and growth: An alternative empirical approach.

Sirowy, L., \&Inkeles, A. (1990). The effects of democracy on economic growth and inequality: A review. Studies in Comparative International Development, 25(1), 126-157.

Subhani, M. I., Osman, M., \&Lakhiya, Z. (2011).The Structure and Performance of Economy of Pakistan (Comparative Study between Democratic and NonDemocratic Governments).

Tavares, J., \&Wacziarg, R. (2001). How democracy affects growth. European economic review, 45(8), 1341-1378. 


\section{APPENDIX}

Table 4.1

\begin{tabular}{|lll|}
\hline & Mean value & Best Under \\
\hline Variable & 5.996970 & Non-Democratic \\
\hline GDP GROWTH RETE (\%) & .68 & Non-Democratic \\
\hline FDI(\% OF GDP) & 4656.981 & Non-Democratic \\
\hline EXPORTS(\% OF GDP) & 6407.9620 & Democratic \\
\hline IMPORTS((\% OF GDP) & 5.810507 & Non-Democratic \\
\hline CPI(\% CHANGE) & 2438.50 & Non-Democratic \\
\hline TOTAL RESERVES(Mn) & 2.360428 & Democratic \\
\hline PERMANAT DEBT(Mn) & 56659 & Non-Democratic \\
\hline FLOATING DEBT(Mn) & 325.80 & Non-Democratic \\
\hline FOREIGN AID(Mn) & 7047.91 & Non-Democratic \\
\hline ELETRICITY CAPACITY(MW) & 30329.94 & Non-Democratic \\
\hline ELECTRICITY GENERATION(GWH) & 592424 & Non-Democratic \\
\hline HEALTH EXPENDITURE(\% of GDP) & 7658.42 & Non-Democratic \\
\hline PRIMARY ENROLLMENT & 912.94666 & Democratic \\
\hline SECONDARY ENROLLMENT & 133394.22 & Non-Democratic \\
\hline COLLEGE ENROLLMENT & 130134.24 & Non-Democratic \\
\hline UNIVERSITY ENROLLMENT
\end{tabular}

Table 4.2

\begin{tabular}{|lll|}
\hline Variable & \multicolumn{1}{c|}{ Variance } & Sig \\
\hline Total Reserves (MN) & EqualVariance Assumed & 0.003 \\
\hline Permanent Debt (MN) & Equal Variance Assumed & 0.010 \\
\hline Floating Debt (MN) & Equal Variance Assumed & 0.000 \\
\hline Health Expenditure (\% of GDP) & Equal Variance Assumed & 0.004 \\
\hline
\end{tabular}

Table 4.3

\begin{tabular}{|l|l|r|r|c|}
\hline \multicolumn{1}{|c|}{ Variable } & \multicolumn{1}{|c|}{ Variance } & Sig 2-tailed & \multicolumn{1}{c|}{$\begin{array}{c}\text { Mean } \\
\text { Difference }\end{array}$} & Better under \\
\hline GDP Growth Rate & Equal Variance Assumed & .002 & -1.9315851 & Non-Democratic \\
& Equal variance Not Assumed & .002 & -1.9315851 & \\
\hline CPI(\% Change) & Equal Variance Assumed & .001 & 5.9946254 & Non-Democratic \\
& Equal variance Not Assumed & .002 & 5.9946254 & \\
\hline Floating Debt & Equal Variance Assumed & .001 & 1.19640 & Non-Democratic \\
& Equal variance Not Assumed & .007 & 1.19640 & \\
\hline
\end{tabular}

